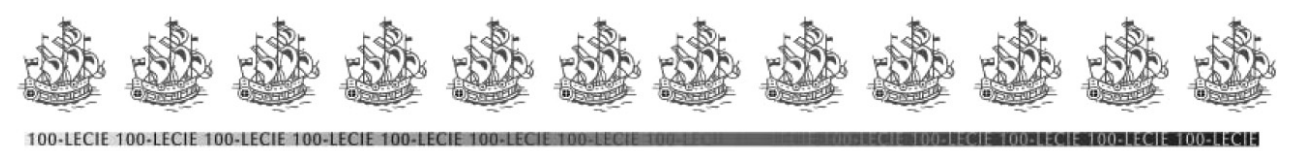

Szkota Grówna Handlowa w WarszaWie 1906 - 2006 Warsaw School of ECONOMICS

Urszula GRZELOŃSKA*

\title{
Aleksy Wakar (1898-1966) ${ }^{1}$
}

1.

Aleksy Wakar urodził się 18 stycznia 1898 w Samarze. Jego matka, Anna z domu Muszkin była Rosjanką, z zawodu - felczerką. Ojciec, Anatol pochodził ze zrusyfikowanej rodziny polskiej (należące do rodziny Wakarów dobra znalazły się w obrębie cesarstwa rosyjskiego po I rozbiorze Polski.) Anatol Wakar był z zawodu prawnikiem i zajmował stanowiska sędziego śledczego i prokuratora; miał on różnorakie relacje z Polską. Polką była jego pierwsza żona, z którą miał m.in. syna, Włodzimierza Wakara (1885-1933), który swoje dojrzałe życie zawodowe związał również z Polską i, co więcej z SGH (był w latach międzywojennych dyrektorem Instytutu Gospodarstwa Społecznego). W roku 1904 przyjechał Anatol Wakar z rodziną w związku z ostatnim swoim zatrudnieniem w Warszawie jako prezes Prokuratorii Generalnej Królestwa Polskiego - urzędu pełniącego rolę arbitrażu. Tak więc Aleksy Wakar spędził dzieciństwo w Warszawie. O swoich losach tak pisze w jednej z wersji własnoręcznie pisanych życiorysów, znajdujących się w Teczce personalnej, przechowywanej w Archiwum SGH-SGPiS: „W 1907 wstąpiłem do 3-go Gimnazjum Warszawskiego, które ukończyłem w 1916 w Moskwie, dokąd przeniesiono Gimnazjum w r. 1915. Następnie wstąpiłem na wydział lekarski Uniwersytetu Warszawskiego w Rostowie (dokąd ewakuowano Uniwersytet Warszawski po rozpoczęciu wojny w 1914 - UG), skąd w październiku tegoż roku przeniosłem się do Akademii Wojskowo Lekarskiej w Piotrogrodzie. Po przewrocie komunist. udałem się na Don, gdzie walczyłem w armiach generałów Korniłowa i Deniki-

Autorka jest pracownikiem Szkoły Głównej Handlowej i Instytutu Nauk Ekonomicznych PAN w Warszawie. Artykuł wpłynął do redakcji w grudniu 2005 r.

1 Jest to czwarta, napisana przeze mnie, wersja biografii Aleksego Wakara jako wyróżniającej się osobowości w dziejach SGH i polskiej ekonomii. Poszczególne wersje różnią się pod względem redakcyjno-ekspozycyjnym i, co ważniejsze, nowymi ustaleniami wynikającymi z coraz większej ilości materiałów z jakimi udało mi się zapoznać. 
na. 3 marca r. 1920 w szeregach armii gen. Bredowa przekroczyłem granicę Polski i zamieszkałem w Warszawie".

$\mathrm{Z}$ innych wersji życiorysu dowiadujemy się, że w Warszawie Aleksy Wakar starał się kontynuować przerwane studia medyczne. Pracował też zarobkowo; w 1921 roku dzięki pomocy brata, Włodzimierza, wówczas prezesa Zrzeszenia Samorządów Powiatowych, podjął pracę jako urzędnik w wydziale Wydawniczym Stowarzyszenia. W latach 1930-1932 zatrudniony był w firmie Elektrolux.

W roku 1927 porzucił ostatecznie medycynę i został słuchaczem Wyższej Szkoły Handlowej. Trzy lata później uzyskał dyplom zawodowy tej uczelni na podstawie pracy „Prawo nieproporcjonalnej wydajności”. Niedługo potem, również na seminarium profesora Władysława Zawadzkiego napisał i obronił pracę magisterską. Poza tym ekonomii uczył się u profesorów Jana Lewińskiego i Edwarda Lipińskiego. Karierę akademicką rozpoczął w 1931 roku prowadząc prywatne seminarium dla studentów i asystentów poświęcone teorii ekonomii. Dzisiaj powiedzielibyśmy, że prowadził koło naukowe. Jak wspomina uczestnik tego seminarium, Jan Drewnowski, dyskutowano na nim przede wszystkim poglądy ekonomiczne Vilfreda Pareta i uczestniczyło w nim przeciętnie 10 osób. Autorytet Wakara jako kierownika był bezsporny. 1 września 1933 roku Aleksy Wakar rozpoczą - na wniosek profesora Edwarda Lipińskiego - pracę w Szkole Głównej Handlowej jako asystent w Katedrze Ekonomii Politycznej. Już po roku otrzymał stopień doktora za rozprawę „Teoria płacy roboczej”. Szybko przygotował następną rozprawę, „Problem ceny zmiennej" i na jej podstawie habilitował się w październiku 1935; w marcu 1936 otrzymał stanowisko docenta SGH. W tym czasie uzyskał obywatelstwo polskie. Pracę na stanowisku docenta zainaugurował wykładem z zakresu teorii wymiany międzynarodowej - tematem, który miał być następnym przedmiotem jego zainteresowania naukowego. Na miesiąc przed agresją Niemiec i ZSRR na Polskę został mianowany profesorem nadzwyczajnym SGH i powierzono mu kierowanie II Katedrą Ekonomii Politycznej, zajmującej się ścisłą teorią.

Po rozpoczęciu okupacji Polski, w 1940 roku został zastępcą kierownika Miejskiej Szkoły Handlowej II-go stopnia w Warszawie i pracował na tym stanowisku do wybuchu powstania warszawskiego w 1944 roku. Kierownikiem tej szkoły był prof. Edward Lipiński i kryła się za nią konspiracyjna SGH; Wakar cały prawie okres okupacji uczył na poziomie uniwersyteckim, prowadził seminaria magisterskie i doktorskie, kontynuował też działalność naukową przygotowując pracę: „Teoria handlu zagranicznego”.

W czasie powstania warszawskiego Aleksy Wakar mieszkał na wsi, w okolicach Łowicza. Wkrótce po wyzwoleniu Warszawy powrócił do miasta i wespół z innymi profesorami przystąpił do wznowienia pracy SGH, uczestnicząc w Komisji Administracyjnej SGH powołanej w celu uruchomienia szkoły w Warszawie (od listopada 1944 działała tajna filia SGH w Częstochowie). Na jednym z pierwszych powojennych posiedzeń Senat SGH wystąpił do ministra oświaty o mianowanie Aleksego Wakara profesorem zwyczajnym w SGH (mianowanie nastąpiło z datą 21.08.1946). Do czasu upaństwowienia Szkoły w 1949 roku pełnił kolejno funkcje: sekretarza Senatu (od pierwszego posie- 
dzenia, które odbyło się 28 marca 1945), rektora Szkoły (wybrany został 8 stycznia 1946), prorektora (w roku akad. 1947-1948), uczestniczył też w rozlicznych komisjach senackich. Ponadto pracował naukowo; kierował Katedrą Ekonomii Politycznej II (katedrą Ekonomii Politycznej I kierował prof. Edward Lipiński).

W 1948 roku władze powierzyły mu stanowisko przewodniczącego specjalnej komisji reorganizującej Akademię Nauk Politycznych, a następnie został mianowany o rektorem tej uczelni. Wtedy też wstąpił do PPR.

W roku 1950 usunięto go z partii pod zarzutem - jak napisał - „kontaktów z emigracją rosyjską w latach dwudziestych". Został też przeniesiony w stan nieczynny, tzn. pozbawiony prawa wykonywania zajęć profesora SGH. W marcu 1952 roku minister szkolnictwa wyższego oddelegował go do Katedry Ekonomii Politycznej na Wydziale Mechanicznym Politechniki Warszawskiej, bez prawa prowadzenia zajęć dydaktycznych ze studentami. Wreszcie, latem 1952 roku został aresztowany przez urząd bezpieczeństwa, przekazany władzom radzieckim i odtransportowany do Moskwy, gdzie wiosną następnego roku skazano go na 10 lat pobytu w obozie pracy.

Uwolniony na mocy dekretu Rady Najwyższej ZSRR powrócił do Polski na dokumentach repatrianta wczesną jesienią 1955 roku. Zgłosił się do pracy w SGPiS, gdzie natychmiast podjął się prowadzenia seminarium, na którym przyswajał swoim młodszym kolegom prace ekonomiczne napisane na świecie w czasie, gdy w Polsce niepodzielnie panowała ekonomia marksistowska. Zaczął współpracować z istniejącym wówczas Instytutem Kształcenia Kadr Naukowych, gdzie sprawował opiekę nad kilkoma młodymi ekonomistami. Po reorganizacji SGPiS powierzono mu kierowanie Katedrą Ekonomii Politycznej na Wydziale Handlu, jedną z pięciu katedr utworzonych na miejsce jednej wielkiej katedry ekonomii politycznej z okresu stalinowskiego. Pozostawał na tym stanowisku od stycznia 1957 roku do śmierci. Zmarł Aleksy Wakar na atak serca 25 sierpnia 1966 roku podczas wakacji spędzanych w Wiśle.

2.

Zostawszy rektorem 1946 roku Aleksy Wakar natychmiast doprowadził do określenia tego, co w dzisiejszej terminologii określilibyśmy jako kierunki i standardy nauczania w SGH, rozstrzygając jednocześnie w prosty sposób problemy, budzące tak wiele dyskusji 60 lat później, na początku XXI wieku - problem kierunków i dwustopniowości studiów ekonomicznych. Już w lutym (12.02) 1946 Senat SGH uchwalił następujący porządek studiów w SGH:

1. „Studia w Szkole Głównej Handlowej w Warszawie trwają trzy lata i dzielą się na dwa okresy: pierwszy, trwający cztery semestry, jednolity dla wszystkich studentów - drugi, trwający dwa semestry, jest zróżniczkowany stosownie do obranego kierunku. Kierunki studiów są następujące: ogólnoekonomiczny, ekonomiki przedsiębiorstw, zagraniczny i gospodarki publicznej". (...). 
5. Po przesłuchaniu sześciu semestrów, zdaniu przepisanych egzaminów, zaliczeniu seminarium magisterskiego i przyjęciu przez Senat pracy magisterskiej student otrzymuje stopień magistra nauk ekonomicznych.

6. Student, który przesłuchał sześć semestrów i zdał przepisane egzaminy, może otrzymać dyplom Szkoły Głównej Handlowej w Warszawie. Dyplom Szkoły Głównej Handlowej jest świadectwem ukończenia Szkoły" (Protokóły posiedzeń Senatu nr 293 - 370 z okresu od 28.03. 1946 do 30.08.1949). Program studiów przewidywał na I roku: 630 godzin wykładów, na II roku - 660 godzin, na III roku - 600 godzin + seminarium ćwiczebne i ćwiczenia z języków.

W sumie było to więcej niż 2000 godzin, gdyż do podanych liczb godzin na I i II roku studiów trzeba również dodać godziny ćwiczeń z dwóch obowiązkowych języków obcych. W programie studiów były uwzględniane wykłady w językach obcych wybranych przez studenta. Oprócz podstawowych studiów SGH prowadziła odpłatne studia specjalistyczne organizowane i współfinansowane przez agendy administracji i gospodarki (planowania, bankowości, rachunkowości i wielu innych). Studenci SGH mogli zapisywać się na owe studia od III-go semestru.

Senat zajmował się szczegółowo obsadzaniem wykładów w uczelni w Warszawie i w istniejącym przez cały okres powojennej działalności SGH oddziale w Łodzi; odpowiednie propozycje zgłaszała Komisja Programowa i Kandydatur na Wykłady. W okresie rektorowania Aleksego Wakara szczególną aktywnością odznaczały się komisje: odbudowy gmachu SGH, tocząca niekończące się boje z pierwszymi socjalistycznymi wykonawcami robót budowlanych, i komisja wydawnicza, troszcząca się zarówno o podaż materiałów do wydawania, jak i o stabilne stosunki Szkoły z wybranym wydawcą. Ponadto bardzo dużo, prawdopodobnie zbyt dużo uwagi, jak na instytucję edukacyjną poświęcać musiały władze szkoły sprawom finansowym. Prawie na każdym posiedzeniu Senatu - jak dyżurne prowadzono dyskusje o tym, jak zbilansować wydatki ciągle niedostatecznymi wpływami Szkoły oraz zajmowano się sprawami warunków życiowych kadry naukowej, administracyjnej i zabezpieczeniem materialnym wdów i sierot po pracownikach szkoły. SGH jako uczelnia prywatna, utrzymywała się z opłat czesnego, które - uwzględniwszy ogromne zubożenie społeczeństwa w wyniku wojny - nie mogły wystarczyć dla pokrycia wydatków obejmujących koszty odbudowy pomieszczeń Szkoły.

Prawie od początku powojennego funkcjonowania SGH Szkoła i osobiście Aleksy Wakar zaczęli przystosowywać się do nowej sytuacji społeczno-politycznej. Po kilku latach, w roku 1955 tak wyjaśniał swoje stanowisko zajęte w latach czterdziestych. „Doceniając w pełni pozytywny wkład Polskiej Partii Robotniczej w budowie Polski Ludowej od samego początku postawiłem siebie do jej dyspozycji, zaś w 1948 r. w związku z mianowaniem mnie rektorem ANP, wstąpiłem w jej szeregi".

Wakar z pewnością był świadomy dokonujących się w Polsce głębokich przemian ustrojowych, politycznych i gospodarczych. W czasie gdy sytuacja się „znormalizowała” - gdy Bierut został prezydentem, powołano rząd komuni- 
styczny i pracował Sejm, gdy przyjęto małą konstytucję, podjął próbę przygotowania intelektualnego środowiska SGH do zaadaptowania się do nowej sytuacji. We wrześniu 1947 roku (30.09.) na posiedzeniu Senatu jako urzędujący prorektor i przewodniczący Komisji Nauki zaproponował cykl naukowych konferencji poświęconych marksizmowi, po czym je perfekcyjnie przygotował i zorganizował. Treść referatów i przebieg dyskusji zapisali ówcześni asystenci SGH. Świadczy ona nie tyle o chęci przyswojenia, ile o próbie oswojenia marksizmu. Referentami poszczególnych problemów gospodarczych widzianych przez pryzmat ustroju socjalistycznego byli profesorowie SGH z Warszawy i z Łodzi; konferencje na poszczególne tematy odbywały się bowiem w Warszawie i w Łodzi z kilkudniowym odstępem.

Prawdopodobnie w ramach tej adaptacji na posiedzeniu Senatu SGH 14 grudnia 1948 roku podjęto uchwałę z okazji zjednoczenia PPR i PPS, w której pisano o radości z powodu zjednoczenia polskiego ruchu robotniczego, zobowiązywano się do pełnego przystosowania programu Szkoły, porządku studiów i nauczania do potrzeb odbudowy i przebudowy życia gospodarczego pod przewodnictwem klasy robotniczej. Tekst tej uchwały wyglądał naprawdę egzotycznie wśród takich normalnych spraw senackich, jak nagroda dla magistranta $\mathrm{X}$ czy awans pracownicy biblioteki o jedną grupę zaszeregowania. Wkrótce potem sprawy posunęły się niebezpiecznie dalej. W przytaczanych już tutaj protokółach z posiedzeń Senatu, pod datą 30 stycznia 1949 roku znalazł się zapis mówiący, że „prof. Wakar odczytał deklarację Koła Partyjnego Pracowników Naukowych SGH. W deklaracji została podkreślona konieczność przyśpieszenia prac nad reformą studiów w Szkole; całkowite przystosowanie tej reformy do potrzeb obecnego etapu walki o socjalizm w Polsce, szerszy udział w pracach nad reformą czynnika politycznego oraz przedstawicieli młodzieży; szybkie wprowadzenie reformy w życie; naukowe pogłębienie w duchu teorii marksizmu-leninizmu zagadnień ekonomiczno-społecznych powstających w toku budowy socjalizmu i w walce klasowej o jego realizację; przyswajanie dorobku naukowego ZSRR w tej dziedzinie; pogłębianie problematyki socjalistycznej produkcji, socjalistycznego przedsiębiorstwa, organizacji i współzawodnictwa pracy, doskonalenie metod i narzędzi planowania gospodarczego, statystyki i rachunkowości, oparcie nauczania innych przedmiotów, głównie zaś dyscyplin społecznych, historycznych i prawnych, na metodzie marksowskiej. Demaskowanie klasowego sensu i klasowo-społecznego charakteru burżuazyjnych nauk ekonomicznych, społecznych i prawnych. Mocne, klasowe związanie Szkoły, całej jej organizacji, administracji i nauki, z nurtem rewolucyjnych przemian społecznych w Polsce".

Senat przeprowadził dyskusję nad przytoczoną deklaracją (w protokóle nie został odnotowany przebieg tej dyskusji) i podjął jednogłośnie (uczestniczyło w tym posiedzeniu 21 osób) uchwałę deklarującą zreformowanie Szkoły w sensie oparcia wykładów o nauki Marksa - Lenina, wprowadzenie dwustopniowości studiów (utrzymania trzyletnich studiów dla uzyskania dyplomu zawodowego i dodatkowego czwartego roku dla uzyskania stopnia magistra, uruchomienia studiów wieczorowych (o mniejszym wymiarze godzin tygodniowo, a więc trwającym dłuższy okres czasu), a wreszcie upaństwowienia Szkoły i zmiany nazwy 
dla lepszego uwydatnienia jej charakteru. Postulowano rozszerzenie programu stypendialnego dla studiującej młodzieży i budowę nowego gmachu dydatycznego dla uczelni. Powyższe zmiany i postulaty, a także wiele drobniejszych zostało ujęte w trzech częściach w układzie: cele, środki i konieczne warunki.

Wszystkie te przygotowania koncepcyjne i organizacyjne nie na wiele się jednak zdały, gdyż nie znalazły uznania u ówczesnych władz politycznych i oświatowych. Te - jak wspomina wiele lat później prof. Leon Koźmiński planując utworzenie w miejsce SGH uczelni socjalistycznej wysłały w 1948 roku po naukę do Moskwy, do Instytutu Plechanowa własną grupę uczonych - późniejszych profesorów Szkoły Głównej Planowania i Statystyki. Byli to: W. Brus, B. Minc, K. Owoc, L. Pawłowski, M. Pohorille i S. Żurawicki.

Organizacyjne i intelektualne zaangażowanie Aleksego Wakara w przemiany ustrojowe, podejmowanie wykładów z ekonomii marksistowskiej i z zakresu problematyki gospodarczej ZSRR wzbudzało zdumienie i niechęć ze strony sporej części profesorskiego środowiska SGH, nawet po wielu latach niektórzy dawniejsi koledzy odnosili się do Niego w sposób znamiennie oziębły.

\section{3.}

Ekonomia, jaką uprawiał Aleksy Wakar w latach trzydziestych, a więc w początkowym okresie swojej kariery ekonomisty, mieściła się w głównym nurcie światowej ekonomii tego okresu. Polegała na przystosowaniu teorii gospodarki konkurencyjnej do warunków gospodarki monopolistycznej czy szerzej warunków konkurencji monopolistycznej. Wakar podejmował tę samą problematykę, którą w Anglii - wówczas centrum badań ekonomicznych - rozwijali Piero Sraffa, Joan Robinson czy John Richard Hicks, a spośród polskich ekonomistów - pracujący w Chicago Oskar Lange. O ile jednak punktem wyjścia dla przykładowo tu wymienionych ekonomistów była neoklasyczna ekonomia Alfreda Marshalla, o tyle Wakar odwoływał się do teorii równowagi ogólnej szkoły lozańskiej. Wpłynął na to fakt, że jego nauczycielem ekonomii był Władysław Zawadzki, który upowszechniał w Polsce zręby tej szkoły. Wakar do końca życia posługiwał się pewnymi konstrukcjami myślowymi, które poznał w „Zastosowaniu matematyki do ekonomii politycznej” Zawadzkiego. W nurcie teorii równowagi ogólnej mieściły się wszystkie przedwojenne prace Aleksego Wakara: z 1935 roku „Teoria płacy roboczej”, z 1936 roku „Zagadnienie ceny zmiennej” i wreszcie książka, nad którą pracował jeszcze podczas wojny i która przyniosła mu największe uznanie jako ekonomiście, opublikowana w 1947 roku „Teoria handlu zagranicznego”.

Od początku zajmowania się ekonomią Aleksy Wakar miał ukształtowany pogląd na temat roli ekonomii w życiu gospodarczym. Swoje credo dotyczące funkcji teorii ekonomii wyłożył w dwóch opracowaniach opublikowanych w 1938 roku (Zasady naukowego badania zjawisk gospodarczych i Ekonomia polityczna i jej zastosowanie). Teoria ekonomii - twierdził - jako nauka o zjawiskach gospodarczych, jest nauką ścisłą, tak jak biologia czy chemia teoretyczna, 
jest nauką opisową a nie normującą przebieg życia gospodarczego. „Badamy rzeczywistość gospodarczą - pisał - głównie po to, aby ją poznać, podobnie jak podróżnik zapuszczający się w głąb nowych lądów nie myśli na razie o kości słoniowej, o rzadkich gatunkach drzewa, nafcie, węglu itp.”. Nie wszystkie elementy składające się na anatomię życia gospodarczego przyciągają uwagę ekonomisty. Elementy te - to cele, środki i decyzje. Zarówno cele, jak i środki są „pozanaukowe”. Pierwsze - cele - nie podlegają weryfikacji naukowej; drugie - środki - są obiektami materialnymi, a ich badanie jest domeną inżynierów i technologów. Przedmiotem badania ekonomisty jest proces podejmowania decyzji. Ekonomista - teoretyk rozpoznaje prawidłowości w decyzjach podejmowanych przez państwo, przedsiębiorcę i konsumenta, wykrywa zasady decyzji racjonalnych, czyli takich, które w gruncie rzeczy podejmuje praktyk gospodarczy. Nie znając jednak teorii ekonomii, a nawet mając poglądy całkowicie sprzeczne z elementarnymi twierdzeniami tej nauki, praktyk dochodzi do tych decyzji kosztem dużej liczby prób i marnotrawstwa czynników wytwórczych. Naukowa wiedza ekonomiczna pozwala, w części przynajmniej, uniknąć tego marnotrawstwa, zmniejszyć liczbę chybionych prób. Łączność między teorią ekonomii i praktyką gospodarowania powinni zapewnić przedstawiciele nauk szczegółowych, czyli specjaliści w zakresie np. bankowości, skarbowości, polityki celnej, których rola polega właśnie na ustalaniu - na podstawie prawidłowości wykrytych przez teorię ekonomii - wzorowych sposobów postępowania w różnych sferach życia gospodarczego.

W latach 30. Aleksy Wakar nie miał w Polsce partnerów do uprawiania ekonomii, partnerów reprezentujących podobne podejście do procesów gospodarczych i stosowane narzędzia analizy. Prawdopodobnie najbliższy mu był nieco tylko młodszy doświadczeniem badawczym Jan Drewnowski, który jednak drugą połowę lat 30. spędzał w Anglii; natomiast po wojnie w środowisku SGH pojawiło się kilku młodych ekonomistów zdolnych do kontynuacji tego nurtu badawczego, jaki zapoczątkował Wakar; obok Jana Drewnowskiego, który powrócił do kraju, wymienić tu trzeba Jana Lipińskiego, Józefa Zagórskiego, Wiesława Sadowskiego. Jednak sprawy ekonomii i procesów gospodarczych poszły w zupełnie innym kierunku.

Po powrocie z ZSRR w połowie lat 50. Aleksy Wakar zaczał pracować nad teorią gospodarki centralnie planowanej. Pozostaje wierny wyłożonym tu wyżej dyrektywom metodologicznym, które później stały się jednym z wyznaczników tzw. szkoły wakarowskiej w polskiej ekonomii. W pracy tej, którą zajmował się aż do śmierci, wyodrębnić można trzy etapy. W etapie pierwszym Wakar pracuje prawie samotnie i kończy go w 1958 roku wydaniem skryptu pt. „Ekonomia polityczna socjalizmu”, w którym wykłada koncepcję określaną później jako teoria rachunku pośredniego. W teorii rachunku pośredniego wykorzystał reguły myślenia i narzędzia, w jakie wyposażyła go znajomość teorii równowagi ogólnej. Zrezygnował na zawsze z próby oswajania marksizmu, natomiast podjął się oswojenia gospodarki planowej przedstawiając ją w kategoriach równowagi ogólnej. Wykazał wówczas, że możliwe jest w takiej gospodarce podjęcie efektywnych decyzji i osiągnięcie równowagi. 
W modelu Wakara decyzje podejmowane były „W imieniu” przedsiębiorstw działających jak gdyby w warunkach konkurencji doskonałej, planowy charakter tej gospodarki wyrażał się w narzuceniu z zewnątrz wielkości konsumpcji (i akumulacji) oraz struktury konsumpcji (zaprzeczał idei tzw. suwerenności konsumenta). Te przyjęte z zewnątrz rozstrzygnięcia reprezentowały tzw. preferencje ogólnospołeczne. Koncepcja rachunku pośredniego mieści się niewątpliwie w całej serii modeli socjalizmu powstałych w ramach dyskusji o racjonalności gospodarki planowej rozpoczętej w latach 20. XX wieku przez Ludwika Misesa. Wakar nie nawiązał otwarcie do tej dyskusji (zrobił to pierwszy z Jego ówczesnych doktorantów, Janusz G. Zieliński, w swojej pracy doktorskiej, „Rachunek ekonomiczny w socjalizmie”). Koncepcja rachunku pośredniego A. Wakara była prawdopodobnie najbliższa myśleniu Jana Drewnowskiego wyrażonemu w jego pracy habilitacyjnej, „Próba ogólnej teorii gospodarki planowej" (Warszawa, 1947), obaj ekonomiści korzystali bowiem z tego samego źródła inspiracji - teorii równowagi ogólnej w ujęciu Władysława Zawadzkiego.

Etap drugi rozpoczyna Aleksy Wakar od konstatacji, że teoria rachunku pośredniego jako koncepcja "modelowa", podobnie jak wiele konstruowanych wówczas i wcześniej modeli socjalizmu nie jest uogólnionym opisem życia gospodarczego w socjalizmie, nie nadaje się więc do „ustalenia wzorowych sposobów postępowania w różnych sferach życia gospodarczego" i rozpoczął konstruowanie teorii, znanej jako teoria rachunku bezpośredniego. Pracował nad nią już w zespole złożonym z młodych naukowców, którzy weszli w skład utworzonej w 1957 roku Katedry Ekonomii Politycznej. Drugi etap zakończył się w 1965 roku wydaniem zespołowej książki pt: „Zarys teorii gospodarki socjalistycznej" (Warszawa, 1964). Rok wcześniej wydana została samodzielna praca Wakara pt: „Morfologia bodźców ekonomicznych”, gdzie nakreślone zostały zręby wakarowskiej teorii planowania i zarządzania w gospodarce socjalistycznej. Gospodarka podzielona w niej została na dwa wielkie procesy decyzyjne, planowania i zarządzania. W procesie planowania nie są wykorzystywane ceny i pieniądz, operuje się wielkościami naturalnymi, stąd nazwa koncepcji: teoria rachunku bezpośredniego. Procesy zarządzania Wakar i wakarowcy (bo od tego czasu można już mówić o dziele zespołu, a nie samego Wakara) opisywali w kategoriach „formuły zarządzania” wyróżniając tzw. formułę parametryczną, wykorzystującą ceny i pieniądz oraz formułę nieparametryczną, operującą poleceniami wyrażonymi w wielkościach naturalnych.

Zarządzaniu, czyli wykonaniu planów gospodarczych poświęcano w koncepcji Wakara znacznie więcej uwagi niż budowie planu gospodarczego. Rozróżniano dwie kategorie wykonawców: tzw. kierowników, czyli szefów socjalistycznych przedsiębiorstw i personel tych przedsiębiorstw, czyli reprezentantów „pracy wykonawczej”. Z dzisiejszej perspektywy to co w wakarowskiej koncepcji zarządzania kierownikami, podporządkowania ich decyzji planowi centralnemu wyrazić można jako problem principal - agent; natomiast problem podporządkowania pracy wykonawczej decyzjom planu gospodarczego widziano w oddziaływaniu społeczno-motywacyjnym. W początku lat 60 . minionego wieku, kiedy Wakar z zespołem pracował nad teorią zarządzania w go- 
spodarce nauka o zarządzaniu była jeszcze na początkowym etapie rozwoju, to, co napisano na temat integrowania robotników wokół planów gospodarczych wywodziło się z socjologii przemysłu i z pierwszych koncepcji zarządzania (w pracy magisterskiej, którą wtedy pisałam pod kierunkiem profesora Wakara referowałam koncepcje Eltona Mayo - amerykańskiego guru stosunków przemysłowych z przełomu lat 50. i 60 . XX wieku).

Etap trzeci obejmuje tworzenie, w oparciu o ogólną teorię, „wzorowych sposobów postępowania w różnych sferach życia gospodarczego". Mówiąc mniej enigmatycznie, etap ten obejmuje tworzenie przez Wakara i jego zespół teorii handlu wewnętrznego, teorii pieniądza i teorii handlu zagranicznego. Wszystkie te szczegółowe teorie wyłożone zostały w książkach, z których tylko „Teoria handlu wewnętrznego", przedstawiająca koncepcję upowszechnianą jako tzw. usługowa teoria handlu opublikowana została za życia Aleksego Wakara. W każdej z tych szczegółowych teorii Wakar zaproponował koncepcję na tyle wyrazistą, że zelektryzowała środowisko i stała się początkiem żarliwych sporów sprawiając, że w środowisku ekonomistów pojawiło się pojęcie szkoły wakarowskiej, które zyskało bezprecedensową popularność.

W nauce o handlu wewnętrznym Wakar zaproponował w miejsce dotychczasowego pojmowania tej sfery działalności jako szybkiego i sprawnego kierowania dóbr od producentów do konsumentów pojmowanie handlu jako usługi polegającej na wyręczaniu konsumentów z konieczności utrzymywania zapasów konsumpcyjnych, z kompletowania dóbr w odpowiednich zestawach w odpowiednim miejscu i czasie, stąd koncepcja „usługowej” teorii handlu. Zajmując się handlem zagranicznym w gospodarce socjalistycznej Wakar wyeksponował znaczenie importu. W panujących wówczas poglądach nacisk kładziono na eksport jako na wyznacznik konkurencyjności i nowoczesności gospodarki, Wakar natomiast utrzymywał, że z punktu widzenia pomyślności gospodarki jednego kraju istotniejszy jest import. Na eksport patrzył jako na nakład używany do uzyskania dobra importowanego i stąd „metoda wytwarzania" jaką widział w handlu zagranicznym pozwalała na uzyskanie dowolnego dobra (importowanego) z dowolnego dobra (eksportowanego). Wreszcie w pieniądzu widział Wakar ważny środek hamujący ekspansywny charakter bodźców stosowanych w układzie planiści - kierownicy przedsiębiorstw realizujący plany (w socjalistycznych relacjach principals - agents). Mianowicie gdy stosowane wobec wykonawców plany bodźce skłaniają ich do zgłaszania nieograniczonego zapotrzebowania na środki służące do wytwarzania dóbr stanowiących zadania planu, ograniczeniem tego zapotrzebowania może stać się ograniczona ilość pieniądza stawiana do dyspozycji wykonawców planu. Stąd pojawiła się koncepcja pieniężnego hamulca ekspansywnych formuł zarządzania. Później koncepcja ekspansywnych formuł zarządzania została rozwinięta przez wakarowców $\mathrm{z}$ wyeksponowaniem systemowego charakteru tej ekspansywności jako źródła trwałej nierównowagi gospodarki (Równowaga gospodarcza w socjalizmie J. Beksiaka i U. Libury) co stało się początkiem krytycznego nurtu w teorii gospodarki socjalistycznej, chyba nie mieszczącego się w pragmatycznej orientacji Aleksego Wakara. Niezależnie od Wakara podobny, 
krytyczny nurt w ekonomii socjalizmu uprawiał węgierski ekonomista Janos Kornai prezentując koncepcję sztywnego i łagodnego (twardego i miękkiego) ograniczenia budżetowego socjalistycznych przedsiębiorców.

O szkole wakarowskiej w polskiej ekonomii wiele mówiono jeszcze za życia Aleksego Wakara, a głównie po jego śmierci. Wiele powstało nieporozumień, zwłaszcza że na dorobek każdego badacza patrzy się z perspektywy tego, kto patrzy i czasu w jakim patrzy. Dzisiaj, to znaczy, prawie 40 lat po śmierci profesora o szkole wakarowskiej można mówić w trzech wymiarach.

Pierwszy wymiar - materialny - to prace, jakie członkowie szkoły wytworzyli. Produktem szkoły wakarowskiej to napisane przez samego Wakara i jego bliższych i dalszych uczniów i współpracowników prace zespołowe z teorii gospodarki centralnie kierowanej, i indywidualne prace doktorskie i habilitacyjne, opublikowane w latach 1961-1975. Szkoła wakarowska zaczęła się serią zeszytów zatytułowanych "Materiały do studiowania ekonomii politycznej socjalizmu” a zakończyła publikacją podręcznika „Ekonomia polityczna socjalizmu”, w 1973 roku. Dzisiaj nikt tych prac nie czyta, chociażby z tego powodu, że nie ma już gospodarki centralnie kierowanej.

Drugi wymiar szkoły wakarowskiej oznacza określoną metodę uprawiania ekonomii; metoda ta ukształtowała się w nawiązaniu do tego rozumienia znaczenia teorii ekonomii, jakie Wakar prezentował w publikacjach z 1938 roku. Są dwie cechy wyróżniające tę metodę. Pierwszą jest wybór przedmiotu badań; mianowicie ekonomistę interesuje to, jak podejmuje się decyzje gospodarcze, a nie to, jakie decyzje gospodarcze są podejmowane. $\mathrm{W}$ terminologii upowszechnianej w latach 70. minionego wieku, a wprowadzonej do ekonomii przez Janosa Kornai'a można powiedzieć, że przedmiotem zainteresowania ekonomisty jest sfera regulacji, a nie sfera realna gospodarki. Przykładowo więc: dla ekonomisty teoretyka ważne jest, kto $\mathrm{w}$ gospodarce i na jakiej podstawie podejmuje decyzje inwestycyjne, ale jest obojętne, czy decyzje te przynoszą gospodarce „nowoczesność” czy też nie. Ważne jest, jak odbywa się dystrybucja dochodu między poszczególne grupy społeczne czy jednostki, czy sposób dystrybucji nie jest sprzeczny ze sposobami podejmowania decyzji dotyczących innych aspektów życia gospodarczego, ale bieda czy bogactwo jako takie nie interesują teoretyka ekonomii. Drugą cechą jest specyficzne dla szkoły wakarowskiej połączenie ujęcia opisowego i normatywnego. Wakar przedstawiał się jako zwolennik opisu. Jest to jednak opis szczególnego rodzaju. Nie polega na opisywaniu tego, co każdy widzi, ale na wykrywaniu w konstrukcji systemu gospodarczego cech istotnych i eksponowaniu w tej konstrukcji tych cech, które czynią ją stabilną i zdolną do życia. Ponieważ taki teoretyczny opis oznacza eksponowanie pewnych procedur, formuł itp., przy jednoczesnym negliżowaniu innych, przeto teoria sprawia wrażenie ujęcia postulatywnego, postulującego jedne i negującego inne sposoby podejmowania decyzji gospodar- 
czych. Taka „postulatywność” nie ma wiele wspólnego z praktyką formułowania wobec polityków gospodarczych otwartych rekomendacji dotyczących konstrukcji systemu gospodarczego i/lub ukształtowania pewnych zmiennych gospodarczych, a wynikających z uznania, że sprawy w gospodarce nie idą w dobrym kierunku.

Trzecim wymiarem szkoły wakarowskiej jest swoisty zespołowy styl pracy naukowej, prawdopodobnie styl nie do powtórzenia bez Wakara. Polegał on na tym, że każdy większy problem mający być przedmiotem badań był najpierw formułowany przez Wakara - przez szefa i rozdzielany na węższe kwestie, wymagające szczegółowego rozpoznania. Wstępne sformułowanie problemu Wakar publikował, najczęściej w formie artykułu. Następnie członkowie zespołu (w latach 1961-1965 stanowili go asystenci i adiunkci pracujący w Katedrze Ekonomii Politycznej na Wydziale Handlu SGPiS) pracowali nad zleconą mu przez szefa kwestią. (Prawdopodobnie podobną metodę zastosował przygotowując w 1947 roku cykl wspomnianych wyżej konferencji naukowych poświęconych marksizmowi.) Pracowało się w zespole Wakara z niezwykłą systematycznością. Każdy ze współpracowników co tydzień, najdalej w dwutygodniowym odstępie prezentował wyniki swoich bieżących dociekań odczytując przygotowany tekst $\mathrm{w}$ grupie o kilkuosobowym względnie stałym lub na bieżąco dobieranym składzie. Szef, a także inni członkowie małej grupy na bieżąco komentowali, krytykowali i korygowali proponowane ujęcia. Gdy kwestia była już prawie rozpracowana, przedstawiano ją na seminarium naukowym katedry, które to seminaria odbywały się z bezprzykładną punktualnością, co piątek, o godzinie 14 . Niezależnie od tego, czy pracowano nad rozdziałem planowanej pracy zbiorowej czy nad indywidualną pracą doktorską czy habilitacyjną, profesor prawie nigdy nie „brał do czytania” całych tekstów, ale każdy był mu w istocie kilkakrotnie odczytany w ciągu licznych spotkań małych grup roboczych. Wszyscy członkowie zespołu znali więc na bieżąco wszystkie pomysły naukowe szefa, a także problematykę badawczą wszystkich członków zespołu, bardzo ściśle zresztą za sobą powiązaną.

Z czasem Aleksy Wakar rozszerzył zespół badawczy, zwłaszcza gdy zaczął zajmować się teorią handlu, obejmując zasięgiem swojego naukowego oddziaływania większość pracowników Wydziału Handlu SGPiS, a także praktyków gospodarczych. Doprowadził wówczas (był to już trzeci okres jego aktywności po powrocie z łagrów) do utworzenia Instytutu Podstawowych Problemów Handlu, nieformalnej, w dzisiejszej terminologii - wirtualnej organizacji skupiającej grono ekonomistów i socjologów pracujących nad problemami tzw. usługowej teorii handlu.

Jako ciekawostkę można przypomnieć fakt, że prace pisane w zespole Aleksego Wakara (z wyjątkiem prac na stopień) zawsze publikowane były jako prace zespołowe a nie zbiorowe. Nie eksponowano autorstwa poszczególnych fragmentów, istotnie trudnych do ustalenia, a uzyskiwane honoraria zawsze dzielono w równych częściach między członków zespołu.

Kończąc tę prezentację szkoły wakarowskiej trudno oprzeć się przed przytoczeniem jednej z opinii o samym Wakarze. Jeden z profesorów SGH-SGPiS 
pisał: „Nie znam drugiego tak efektywnie prowadzonego seminarium, jak wakarowskie. Potrafił on swoim podopiecznym pracownikom narzucić duże tempo pisania dysertacji doktorskich i habilitacyjnych i to absolutnie nie kosztem ich jakości. "sekret« jego pracy polegał - jak sądzę - na tym, że wymagał od nich bardzo dużo, ale od siebie wymagal znacznie więcej, o czym oni doskonale wiedzieli. Był to jeden z bardzo nielicznych profesorów, którzy bardzo często odwiedzali Bibliotekę Szkoły, godzinami w niej pracując. Mógł sobie na to pozwolić, gdyż nigdy nie dzielił swojego dnia pracy na dwa etaty". Ten cytat chyba wystarczająco tłumaczy, dlaczego szkoła wakarowska jest fenomenem niezwykle trudnym do powtórzenia.

\section{5.}

Po zarysowaniu sylwetki Aleksego Wakara jako rektora i działacza oraz jako uczonego pora jest przypomnieć go nieco jako człowieka.

Z wyglądu zewnętrznego był wysoki, szczupły, o bardzo wytwornych ruchach i stonowanym głosie, sprawiał wrażenie jak gdyby trochę nieśmiałego.

W latach gdy pracował w SGH - SGPiS bardzo mało udzielał się zawodowo poza uczelnią. Przez rok, tuż przed wojną, prowadził kronikę radiową na temat: „Nauki ekonomiczne”. Również przed wojną aktywnie działał w Polskim Towarzystwie Ekonomicznym. Nie utrzymywał kontaktów z zagranicznymi ośrodkami naukowymi, chociaż był przed wojną członkiem The Econometric Society, którego współzałożycielem był Władysław Zawadzki. Nie podróżował za granicę; ze znajdującego się w Jego Teczce personalnej w Archiwum Szkoły podania o udzielenie mu półrocznego urlopu wiadomo, że w 1949 roku zamierzał udać się do Moskwy w celu prowadzenia tam badań naukowych. We wrześniu 1966 roku wybierał się do NRD, do Berlina na konferencję poświęconą problemom handlu, pokrzyżowała mu te plany śmierć.

Frekwencja na wykładach Wakara była raczej przeciętna, grupy seminaryjne nieliczne. Nie należał do oratorów, ale materiał wykładowy miał zawsze starannie opracowany, z dokładnie przygotowanymi ilustracjami graficznymi i przykładami liczbowymi. Jako egzaminator miał wśród studentów mieszane opinie. Opierając się na opiniach jego studentów z czasów SGH i słuchaczy z lat 1957-1966 można powiedzieć, że w tym pierwszym okresie swojej działalności pedagogicznej był egzaminatorem niezwykle surowym i wymagającym, natomiast po przerwie w latach 1950-1957 złagodniał i stał się wyrozumiały.

Nigdy, nie cieszył się wielką popularnością w środowisku ekonomistów, poza zespołem bezpośrednich uczniów i współpracowników. Jakkolwiek nie kwestionowano jego kwalifikacji naukowych i zawodowych, a nawet wysoko je ceniono, ekonomiści reprezentujący odmienne sposoby analizy zjawisk gospodarczych odnosili się do Aleksego Wakara i jego prac z pewną rezerwą. Nie miał prawie do końca życia łatwego dostępu do wydawnictw i innych form upowszechniania prac naukowych. 
Była ta sytuacja w większym stopniu zasługą samego Wakara niż jego środowiska. W publikacjach nie miał wprawdzie zwyczaju prowadzenia wyraźnych polemik, natomiast w bezpośrednich dyskusjach bywał ostry i bezwzględny. Szczególnie przy okazjach obrony prac doktorskich i kolokwiów habilitacyjnych zdecydowanie prezentował swoje stanowisko, zwalczał poglądy jego zdaniem nienaukowe, nieuzasadnione czy niedbale sformułowane. $\mathrm{Z}$ charakteru niezbyt towarzyski, całkowicie ignorował istnienie osób jego zdaniem niemądrych lub z którymi poróżniły go wyznawane poglądy czy różne wydarzenia, w których przyszło mu uczestniczyć.

Całkowicie pochłonięty pracą zawodową nie był jednak typem roztargnionego uczonego nieświadomego zawiłości stosunków międzyludzkich, a pogrążonego bez reszty w książkach i teoretycznych problemach uprawianej nauki. Przeciwnie, zawsze znał przysługujące mu z obyczaju czy przepisu uprawnienia, jakkolwiek nigdy ich nie nadużywał, dostrzegał interesy łączące lub dzielące ludzi i z talentem je wykorzystywał.

Co pozostało po Nim, wielkiego formatu ekonomiście, oprócz sterty książek opisujących system, który zginął w mrokach historii. Co najmniej jedna sprawa nasuwa się natychmiast po powyższym pytaniu. Aleksy Wakar, podejmując na seminariach i w wykładach prowadzonych w latach 50. i 60. egzotyczną wówczas tematykę równowagi ogólnej, neoklasycznej teorii przedsiębiorstwa, teorii Keynesa czy opis instytucji gospodarki pieniężno-kredytowej w kapitalizmie sprawił, że wiele lat później stał się możliwy względnie gładki powrót SGPiS - SGH do normalnej ekonomii.

\section{ALEKSY WAKAR (1898-1966)}

\section{Summary}

Prof. Aleksy Wakar was an outstanding graduate and professor of the Warsaw School of Economics. He began his studies at SGH at the age of almost 30, following his tempestuous experiences during the Russian Revolution and the Civil War of 1917-1921. Several years of research work after graduation enabled him to write three significant books that eventually resulted in his promotion to professor. After World War II, Wakar excelled in organizational work. As rector and pro-rector of the school, he was in charge of the curriculum and the selection of lecturers. After a several-year hiatus (1950-1955) when he was imprisoned and detained in Soviet camps, Wakar started another stage of his research work at SGH, then renamed the Main School of Planning and Statistics (SGPiS). Together with his team, he developed an innovative theory of a centrally planned economy and trained a large group of economists who formed what was referred to as the "Wakar school." He was a true master in developing and managing research teams. 